\title{
Bilateral limbal stem cell disease in a patient with Addison's disease
}

\author{
Supriya Sharma, ${ }^{1}$ Somasheila I Murthy ${ }^{\circ},{ }^{2}$ Varsha Rathi ${ }^{1}$
}

${ }^{1}$ GPR-ICARE, LV Prasad Eye Institute, Hyderabad, Telangana, India

${ }^{2}$ The Cornea Institute, LV Prasad Eye Institute, Hyderabad, Telangana, India

\section{Correspondence to} Dr Somasheila I Murthy; smurthy@|vpei.org

Accepted 17 January 2021

\section{DESCRIPTION}

A 43-year-old female patient presented with blurring, pain and foreign body sensation for 18 months. Systemic history was significant for primary adrenocortical insufficiency (PAI) diagnosed 10 years ago following complaints of chronic fatigue and weight loss. She underwent high-dose prednisolone therapy but discontinued medication 2 years ago. At presentation, she was already on topical lubricating eye drops for 3 months.

Best-corrected visual acuity (BCVA) was 6/60 in the right eye (OD) and 6/24 in the left eye (OS). Slit-lamp examination showed bilateral conjunctival congestion, peripheral superficial corneal neovascularisation, superficial punctate keratitis, mild epithelial haze and whorled epithelial pattern (figure 1A,B). Schirmer II test values (at $5 \mathrm{~min}$ ) were $10 \mathrm{~mm}$ in both eyes. The rest of the ocular examination was normal except for the presence of significant posterior subcataracts (OS $>O D)$. A diagnosis of bilateral partial limbal stem cell deficiency (LSCD) secondary to Addison's disease was made. Systemic evaluation revealed serum cortisone levels were low at $43.2 \mathrm{nmol} / \mathrm{L}$ (normal range: $83-359 \mathrm{nmol} / \mathrm{L}$ ). Serum electrolytes, thyroid profile, parathormone levels and blood sugars were normal.

Topical lubricants (hydroxypropyl methylcellulose $0.3 \%$ eye drops once every two hours, sodium hyaluronate $0.1 \%$ eye ointment) two times and tacrolimus $(0.03 \% \mathrm{w} / \mathrm{w})$ eye ointment at bedtime and a short course of topical steroids (loteprednol etabonate $0.5 \%$ ) in a weekly tapering regimen were prescribed. Systemic hormonal replacement therapy was resumed by the endocrinologist. Over 3 months, there was significant improvement in her symptoms with resolution of LSCD (figure 2A,B). BCVA improved to $6 / 12 \mathrm{p}$ in OD, and in OS it remained at $6 / 60 \mathrm{p}$ due to cataract. The peripheral vascularisation and epithelial haze regressed, and residual corneal scarring was noted.
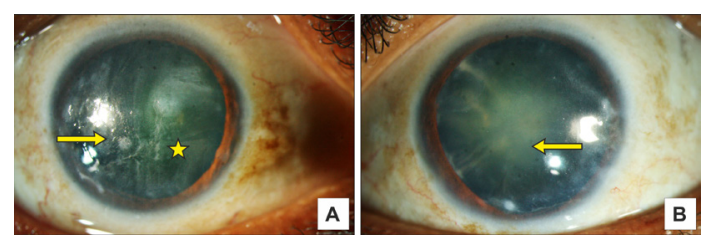

Figure 1 Slit-lamp photograph of the right and left eyes $(A, B)$ showing corneal epithelial haze (arrows), paracentral scarring, 'whorled' pattern of corneal epithelium (asterisk) and peripheral corneal vascularisation at presentation.

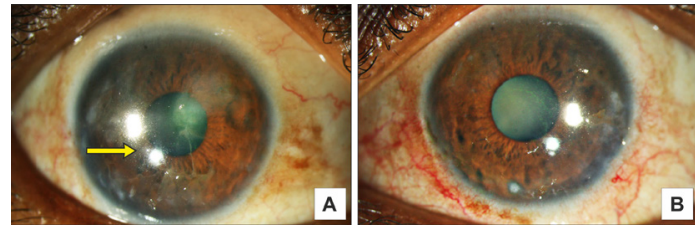

Figure 2 Three months after treatment, there is resolution of haze (arrow) with peripheral scarring (A) and improvement of the corneal surface in both eyes (B).

The limbal stem cells are known to reside in the basal epithelium at the limbus and are responsible for the ocular surface integrity, acting as a mechanical barrier preventing conjunctival epithelial overgrowth over the cornea. Several disorders can lead to LSCD and its sequalae of scarring and chronic inflammation, eventually affecting the vision and patient comfort. ${ }^{1}$

Addison's disease (primary adrenal insufficiency) occurs due to dysfunction of bilateral adrenal cortex manifesting as chronic fatigue, muscle weakness and gastrointestinal disturbances. ${ }^{2}$ Adrenal hormones also regulate the ocular surface health, inhibiting release of cytokines and chemokines that adversely affect limbal stem cells. ${ }^{3}$

Association of LSCD with polyendocrinopathy has been reported previously in literature. ${ }^{45}$ However, those patients had coexisting diseases like idiopathic hypoparathyroidism and autoimmune polyendocrinopathy/candidiasis/ectodermal dystrophy syndrome.

Our case is different from other cases reported previously; her ocular symptoms started after she discontinued her systemic hormonal therapy.

\section{Learning points}

In patients presenting with mild to moderate limbal stem cell deficiency (LSCD) without a definite cause, a diagnosis of an underlying endocrinopathy like Addison's disease should be ruled out.

- These patients have mild symptoms initially, and early diagnosis and treatment can prevent the development of sequalae of LSCD, such as chronic dry eye, persistent epithelial defects and meibomian gland disease.

- Multidisciplinary approach with an endocrinologist helps to keep the systemic disease under check and prevents further complications of a debilitating condition like primary adrenocortical insufficiency. 
Ocular surface inflammation was the first sign at presentation in the absence of other systemic features of PAI. We speculate that similar to other non-specific systemic signs of PAI, LSCD could be an early and subtle sign of this disease.

Acknowledgements Hyderabad Eye Research Foundation, Hyderabad.

Contributors SIM managed the case. SIM, SS and VR drafted the manuscript. SS designed the images. Revision was done by SIM and VR.

Funding The authors have not declared a specific grant for this research from any funding agency in the public, commercial or not-for-profit sectors.

Competing interests None declared.

Patient consent for publication Obtained.

Provenance and peer review Not commissioned; externally peer reviewed.

\section{ORCID iD}

Somasheila I Murthy http://orcid.org/0000-0002-8696-9669

\section{REFERENCES}

1 Le Q, Xu J, Deng SX. The diagnosis of limbal stem cell deficiency. Ocul Surf 2018;16:58-69.

2 Tsai SL, Green J, Metherell LA, et al. Primary adrenocortical insufficiency case series: genetic etiologies more common than expected. Horm Res Paediatr 2016;85:35-42.

3 Susarla R, Liu L, Walker EA, et al. Cortisol biosynthesis in the human ocular surface innate immune response. PLoS One 2014;9:e94913.

4 Örnek N, Örnek K, Ogurel T. Limbal stem cell defficiency associated with primary adrenocortical insufficiency. GMS Ophthalmol Cases 2019;9:9.

5 Mezgueldi E, Bertholet-Thomas A, Milazzo S, et al. Early-Onset hypoparathyroidism and chronic keratitis revealing APECED. Clin Case Rep 2015;3:809-13.

Copyright 2021 BMJ Publishing Group. All rights reserved. For permission to reuse any of this content visit

https://www.bmj.com/company/products-services/rights-and-licensing/permissions/

BMJ Case Report Fellows may re-use this article for personal use and teaching without any further permission.

Become a Fellow of BMJ Case Reports today and you can:

- Submit as many cases as you like

- Enjoy fast sympathetic peer review and rapid publication of accepted articles

- Access all the published articles

Re-use any of the published material for personal use and teaching without further permission

\section{Customer Service}

If you have any further queries about your subscription, please contact our customer services team on +44 (0) 2071111105 or via email at support@bmj.com.

Visit casereports.bmj.com for more articles like this and to become a Fellow 